the battered baby largely in the hands of inexperienced field workers and perhaps go some way towards overcoming the present practice of returning these children home, where re-battering often occurs.-I am, etc.,

SELWYN SMITH

University Department of Psychiatry, Queen Elizabeth Hospital, Birmingham

\section{Diseases in the Tropics}

SIR,-I would like to question the relevance of Dr. W. Z. Conco's remarks about the diseases of civilization (11 August, p. 331). We are told that Dr. Conco "saw Africans not only with coronary heart disease but also with nearly $58 \%$ of the conditions listed by Burkitt and $66 \%$ of those listed by Gelfand as rare." This claim cannot be taken seriously until we are given some idea about the clinical criteria for making his diagnosis, the number of patients involved, and an estimate (at least) of the total number of patients seen over the same period. Presumably the age/sex structure of the population in a Zulu rural area was weighted towards women and children with a moderate number of elderly people. If these data are not available perhaps detailed case studies of these patients could be released.

The value of scientific medical terms as a means of communication with patients is doubtful even in the United Kingdom, as accurate medical histories can be obtained only by avoiding medical jargon. If a patient says that he has diverticular disease, toxoplasmosis, scabies, or migraine he should be asked about his symptoms and environment and then examined to permit formulation of a scientific diagnosis. It is irrelevant whethe or not the patient understands the scientific medical term. Table I in Dr. Conco's paper hides the "English medical terms" he tested thus they cannot be evaluated, but tables II and IV suggest that the terms chosen were often diagnoses.

This publication reinforces my fear that our profession becomes trapped by a desire to use respectable medical labels. Clinician must become more honest about the minimal criteria required before making a diagnosis This approach is being tried in our depart ment and it forces the clinician to use more lay terms, which often describe the clinical situation most accurately. Premature labelling with a pseudo-diagnosis is avoided while our "diagnoses" have accepted minimal confidence limits.

I find table III in Dr. Conco's paper interesting because here are some Zulu lay concepts which need detailed exploration with an open mind free from the shackles of Western medical jargon and dogma. For example, a detailed history of the patient's feelings when he is suffering from umkhondo ("trail disease") and study of a series of such patients could prove useful as an exercise in communication and may contribute new medical knowledge to the African scene. Awareness and analysis of lay and witch doctor descriptions of medical problems ${ }^{12}$ are surely the first steps towards resolving any communication difficulties of developing countries.-I am, etc.,

N. C. H. Sтотт

General Practice Unit,

Welsh National School of Medicine,

Welsh 1 Ingle, R. F., South African Medical foumal, 1973,
47,333 .
2 Stott, N. C. H., and Browne, W. M., South
African Medical foumal, 1973, 47, 334.

\section{Thalassaemia in the British}

SIR,-The recent article by Dr. H. H. M Knox-Macauley and others (21 July, p. 150) and the subsequent letter on this tomic from Dr. J. J. Taylor (11 August, p. 353) have prompted me to record my experience on this subject in Canada.

Over the last eight years my laboratory has conducted a search for abnormal haemoglobin variants and for thalassaemias mainly in the provinces of Alberta, Saskatchewan, and Manitoba and has supplied a service to physicians in the last two provinces for the laboratory diagnosis of these conditions. The diagnosis of $\beta$-thalassaemia trait was made in 132 individuals in 105 families in Saskatchewan and Manitoba on the basis of of haemoglobin patterns, including determination of the $\mathrm{HbA}_{2}$ and $\mathrm{HbF}$ levels, test for raised erythrocyte osmotic resistance, and examination of erythrocyte morphology Thirty-five of these persons $(26.5 \%)$ were considered to be of British origin with no ascertainable history of recent intermarriage with persons of Mediterranean, African, or Asian origin. Nineteen of the $52 \beta$-thalassaemics found in Saskatchewan and 16 of the $\mathbf{8 0}$ found in Manitoba were British. In all of them the $\mathrm{HbA}_{2}$ levels were raised (mean $5.4 \%$, S.D. $\pm 1.13 \%$ in the former mean $5.1 \%, S . D . \pm 0.73 \%$ in the latter; mean $2.2 \%$, S.D. $\pm 0.40 \%$ in a control group) while $\mathrm{HbF}$ levels were normal in about half of these subjects and did not exceed $8 \%$ in the rest. These values are in agreement with those of Dr. Knox-Macauley and his collaborators and indicate that the same $\beta$-thalassaemia gene is probably involved in both series. The propositi in nine of the 25 British families with $\beta$-thalassaemia were detected during population studies. No instances of homozygous $\beta$-thalassaemia or of $\alpha$-thalassaemia were found in British subjects.

These results suggest that at least $20 \%$ of all $\beta$-thalassaemias in central Canada are of immigrant British stock and that in nearly half of them the condition is not suspected clinically. I agree with Dr. Taylor that one of the commonest difficulties to be experienced in these cases is in convincing some colleagues of the diagnosis.-I am, etc.,

Department of Biochemistry,

F. Vella University of Saskatchewa Saskatoon, Saskatchewan,

Canada

\section{Hyperamylasaemia in Diabetic Ketosis}

SIR,-We were interested to note that Dr. A. H. Knight and his colleagues (21 July, p. 128) have confirmed our original observation $^{1}$ that the serum amylase is often considerably elevated in diabetic ketosis and that this phenomenon is not obviously due to pancreatitis.

We did in fact take the matter a little further by studying serial amylase levels during the course of oral glucose tolerance tests in 60 newly diagnosed and untreated diabetics and 52 controls. The curves in each group were summated and mean ourves con- structed. The results indicated that the amylase level rose in normals but tended to fall in diabetics, and the difference was statistically significant. The rise in the amylase level following an oral glucose load in normal subjects could be explained in several ways. It could be that the pancreas is stimulated, leading to an overflow of pancreatic amylase into the circulation, or that oral glucose is initially taken into the liver and the glucose appearing in the blood could be due to breakdown of liver glycogen with overflow of liver amylase into the circulation. It is not apparent why the amylase should behave differently in diabetics. The very high amylase levels in diabetic ketosis could lead to a massive breakdown of liver glycogen, and it is even possible that the hyperglycaemia is a secondary phenomenon In this connexion we have often wondered why the blood sugar should be so high in diabetic ketosis when the patient may have been ill for some days possibly with anorexia and vomiting, which should lower the blood sugar, particularly if the patient has continued to take insulin.

Several workers have doubted whether the serum amylase is simply a passive overflow and have speculated that it may have a primary physiological function. The evidence would now seem to be strong enough to conclude that there are definite abnormalities in amylase metabolism in diabetes, and elucidation of the mechanisms involved may throw some further light on the pathogenesis of diabetes.-We are, etc.,

R. FnNN

Sefton General Hospital,

S. COPE

1 Finn, R., and Cope, S., Diabetes, 1963, 12, 141.

\section{Significance of Pseudomonas aeruginosa in} Sputum

SIR,-Dr. M. W. Burns's article (18 August, p. 382) draws attention to a problem which is increasing in frequency not only in Australia but also in Britain. I would like to make a few comments.

Though there is a tendencr sometimes towards unnecessary antibiotic therapy when pseudomonas is isolated from sputum, Dr. Burns seems to over-estimate this danger. The difficulty of assessing the significance of any organism cultured from sputum is well recognized, and Pseudomonas aeruginosa is no exception. The present method most commonly used in clinical bacteriology laboratories (in Britain) is an examination of the Gram film in conjunction with the findings on culture. In the absence of pus cells in the film, the isolation of pseudomonas from soutum cannot be regarded as a clear indication for antibiotic therapy. (The report from our laboratory always states whether or not pus cells are present in the specimen.) The 34 cases described without clinical infection, in which the organism was considered to be a commensal, would most likely be in the category of non-purulent specimen and the patient would not automatically be put on antibiotics. Dr. Burns does not seem to take the purulence of the specimen into consideration when assessing the importance or otherwise of the isolated pseudomonas.

Another point is that no mention is made of the in vitro sensitivities of any of the pseudomonas isolated. This would have been 
relevant to the choice of treatment and might explain why the pseudomonas in the sputum of one patient "showed no sign of suppression by colistin aerosol." Also, many pseudomonas $(60 \%)$ are sensitive to tetracycline and this might explain the finding that tetracycline is "less likely to be interfered with by pseudomonas" in the treatment of underlying infection.

I would question the presumption that pseudomonas can reach the pharynx by ascending the oesophagus. Though I have cultured many different organisms from the small intestine, I have never found pseudomonas as high as the duodenum in the gastrointestinal tract. There are many other more likely sources of infection, as pseudomonas commonly contaminates hospital equipment (especially ventilators, humidifiers, and suction apparatus), contaminates hospital food, ${ }^{1}$ and is carried on the hands of staff, contaminated by an infected patient.-I am, etc.,

J. S. CARGILl

Department of Bacteriology,

Royal Infirmary, Glasgow

1 Sanders, C. V., Luby, J. P., Johanson, W. G. Internal Medicine, 1970, 73, 15.

\section{Superannuation and the Elderly G.P.}

SIR,-If Dr. R. A. Keable-Elliott regards the correspondence on G.P.s' superannuation with dismay, we, the originators of the correspondence, view his letter (18 August, p. 404) with sinking hearts, for it reflects an attitude of supineness, though naturally we realize that he thinks all is being done that can be done to rectify matters. Surely, however, the Association is not so bereft of bargaining powers as he says, nor was it compelled to agree to an improvement of future pensions at the expense of those of the very pioneers who, with justified misgivings then freely expressed, served the nascent N.H.S. faithfully and now have reaped wretched pensions. Think what they could have done with their goodwill money had not time and politicians robbed it of most of its value before they received it.

Consider this actual case. Two men joined a large partnership practice before the last war, their agreement sensibly stating that they must retire on the 1 April following their 65th birthdays. One went in 1971 and the other in 1973. How can it be other than grossly unjust that the second man has a pension and lump sum more than half as big again as those of the first? Moreover, time will widen the monetary gap. Consider too, the man who retired in 1960-"pension then £336, now £520"; and also ones who retired a few short weeks or months before the fateful day through ignorance of the future, or even were encouraged to do so.

We ourselves only realized the effects of dynamizing by a chance view of the pamphlet sent to G.P.s in practice. We have naturally written to our M.P.s, but letters only get passed on to the Department of Health and Social Security and elicit replies which are not quite honest, for the 1972 Act was made retrospective to a degree, as Dr. Keable-Elliott says, and did not apply only to men in post.

We are not rebels. In our time we have been pillars of the Plymouth Division of the B.M.A. and the Plymouth Medical Society and we are doing what we can to protest at one of the most flagrant pieces of injustice agreed to by the B.M.A. in our lifetime; and we will go on protesting until justice is done in any way open to us. The injustice does not only apply to those who retired between 1969 and 1971 but to all who retired since N.H.S. pensions began in 1958 .

To further our efforts, will Dr. KeableElliott please tell us the number of doctors involved in this dwindling group?-We are etc.,

G. D. J. BALL

C. R. BARKER

Plymouth

T. L. Chester-WILliams

** The authors of the above letter sent a copy of it to Dr. Keable-Elliott, who writes as follows:

SIR,-This letter reiterates the known facts that many G.P.s have unsatisfactory pensions but offers no new solution to the problems we are facing in this field. It also contains a major error of fact; the statement that the B.M.A. was "compelled to agree to an improvement of future pensions at the expense of the very pioneers etc." (my italics) is quite untrue. Never has it been suggested that the package deal should be financed at the expense of retired practitioners, and if it had been suggested it is unthinkable that the negotiators would have agreed.-I am, etc.

Instone, Bucks

R. A. Keable-Elliott

\section{B.M.A and the R.H.C.S.A.}

SIR,-I should be grateful if you would allow me to comment on an article on the B.M.A. and the Regional Hospitals' Consultants and Specialists Association which appeared in the July edition of B.M.A. News. ${ }^{1}$

That article says that there is little fundamental disagreement over policy between the R.H.C.S.A. and the B.M.A. As a past honorary secretary of the R.H.C.S.A. and a present adviser to its council, I must disagree. A fundamental disagreement does exist over the manner in which consultants should be represented. The R.H.C.S.A. believes that consultants should have the right to remove from office any of their representatives with whose views they do not agree or with whose performance they are not satisfied. It believes that this can be achieved only by a system in which consultants directly elect their representatives at regular intervals and when the elections are well publicized. To this end the R.H.C.S.A. has evolved a democratic system based on the principle of one man one vote. The system stands up to the acid test in that there is active participation by the members in the association's affairs.

As I see it, in contrast the B.M.A. believes in an indirect electoral system with the national representatives appointed by all sorts of committees, associations, and royal college councils, many of which are considered to be remote by the grass-roots consultant. The structure is so complex that I doubt if any member of the Central Committee for Hospital Medical Services could say what its constitution is without looking it up. An eminent past member and officer of the C.C.H.M.S. has freely admitted that most consultants do not participate in its affairs. $^{2}$ The B.M.A. News article suggests that talks between representatives of the C.C.H.M.S. and R.H.C.S.A. were held "in order to find out whether there was any means of accommodating the needs of the R.H.C.S.A. within the B.M.A. structure." That may have been the hope of the B.M.A. representatives, but neither the R.H.C.S.A executive nor its council has ever considered such a possibility as a permanent solution to the problem. The R.H.C.S.A. is an independent organization and any subservience to the B.M.A. or representation of its members through B.M.A. institutions would be totally unacceptable. Of course, partnership is something else.

The manner of representation is a matter of fundamental disagreement between the two associations and one of great moment. The R.H.C.S.A. leaders believe that it is not overstating the case to say that it is a question of democracy; about it they feel deeply and passionately and that is why they have continued the fight in spite of the great personal sacrifices they have had to make to do so. It is a matter of principle on which I know they will not yield.-I am, etc.

Potters Bar, Herts

N. A. Simmons

B.M.A. News, 1973, no. 42, p. 5.
Mavon-White. R. M., British Medical fournal, $1973,2,424$.

\section{Points from Letters}

\section{Loin Percussion in Kidney Disease}

Professor L. Katsilabros (Athens) writes: With reference to Dr. B. T.B. Manners's letter (17 March, p. 682) about the diagnostic value of percussion of the renal region in kidney disease, I wish to report a personal modification of this procedure. The patient is placed in the prostrate position with the abdomen lying on a pillow and his arms beside his body in a relaxed position. In cases of pyelitis or acute glomerulonephritis slight percussion is enough to produce severe pain over the costovertebral angle. Costoverfebral tenderness is elicited by this procedure in many patients when it is not observed by the conventional method. I think that when the patient is sitting the tone of the spinal muscles inhibits the production of this sign to a certain extent. ..

\section{Femoral Artery Complications after}

\section{Diagnostic Procedures}

Dr. J. K. Johnson (York) writes: Dr. John Bouhoutsos and Mr. Tom Morris (18 August, p. 396) made no mention of any possible relationship between the size of the needle or catheter used and the risk of subsequent complications. It is my impression that larger needles and catheters are more likely to cause prolonged bleeding than small ones and also that changing the catheter and repeated manipulation is likely to cause increased difficulty in achieving subsequent haemostasis....

\section{Tests of Acupuncture}

Dr. F. S. RICKARDS (Bolton-le-Sands, Lancs.) writes: Sir Robert Macintosh (25 August, p. 454) quotes the successful use of surgery under hypnosis and goes on to say that "acupuncture is an effective use of hypnosis." He predicts that if a leading acupuncturist were to be invited to Britain and be presented with an operation list chosen at random his success rate would be nil. But if acupuncture is hypnosis his success rate would be as effective as hypnosis-which is demonstrably not nil... 